\title{
The Effect of Project-Based Learning (PjBL) Continuing Learning Innovation on Learning Outcomes of English in Higher Education
}

\author{
Abdul Syakur' ${ }^{1}$ Lailatul Musyarofah ${ }^{2}$, Sulistiyaningsih $^{3}$, Wike $^{4}$ \\ ${ }^{1,2,3}$ Department of GraduateProgram of English Education, STKIP PGRI Sidoarjo, Indonesia \\ ${ }^{4}$ Doctoral Environmental Assessment and Development Program, Universitas Brawijaya, Indonesia \\ syakurabdmpd@gmail.com
}

\begin{abstract}
The educational approach that emphasizes creative thinking, problem-solving, and interaction is one that is suitable for sustaining this project-based continuous learning. Participation in the current Process, Input, Output, and Outcome is requested of universities. The educational approach that emphasizes creative thinking, problem-solving, and interaction between students and peers in order to create and use knowledge is one that is suitable for sustaining this project-based learning. The aim of this study is to see how continuous learning technologies like PjBL influence the English learning outcomes of students enrolled in Brawijaya University's English Education study programs. The experimental design for this study was a TimesSeries System with a Control Group. The one-way ANOVA test was used to analyze the data in this study. The findings showed that the treatment of the TOEFL test, specifically the pre-and post-test, differed between the contro and experimental groups by using the Project-Based Learning (PjBL) learning model. The experimental class's average pre-test TOEFL score was 344.71, with a range of 300-397 and a standard deviation of 29.386. The experimental class's average post-test TOEFL score is 360.83 , with a range of values from 303 to 400 and a standard deviation of 24.146. Project-based learning which has a p-value of 0.026, has been shown to improve student's learning outcomes.
\end{abstract}

Keywords

continuous learning innovation;

Project-Based Learning ( $\mathrm{P} B \mathrm{~B})$;

English learning outcomes

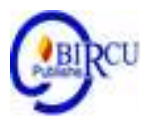

\section{Introduction}

Interactions between students and instructors, students and other students, and students and learning materials will all benefit the learning process. Apart from that, students naturally apply knowledge and engage in mental processes as they link new information to specific and essential concepts (Rangkuti, 2019). In addition to demanding academic ability demands (hard skills), students are also required to be able to improve their abilities (soft skills), so that they are ready to enter the real world of work after completing their studies and there is an important thing to do is to master little TOEFL as a prerequisite for gaining jobs the good one. $\mathrm{PjBL}$ (project-based learning) is a form of education that emphasizes long-term tasks in order to solve complex problems. Students are given multidisciplinary and product-oriented assignments (artifacts) (Mahanal et al, 2010).

Learning that can assist students in thinking creatively, solving problems, and communicating, as well as learning that contributes to the solution of real-world problems, is beneficial. PjBL is a new approach to continuous learning aimed at Education for Sustainable Development (ESD), in which project-based learning can lead to real-world problems. 
Students in the English Language Education study programs at UB Malang's Faculty of Culture may improve their motivation, method, and achievement by applying problems from specific lectures to real-life situations.

The meaning of the word "learning outcomes" refers to the level of mastery attained by students when they learn in accordance with the objectives established. According to Sardiman and Rahardjo (Mansur, 2015), learning outcomes are agreed-upon mastery processes for assessing student success. There are two types of factors that influence learning outcomes: (1) individual factors such as maturity, intelligence, motivation, and personal factors; and (2) social factors such as the teacher, family, and educational media. The outcomes of learning must demonstrate improved conditions, which is why it is beneficial to (1) increase knowledge, (2) increase comprehension, (3) increase skills, (4) have a new perspective, and (5) appreciate something more. The purpose of this study was to determine the effect of PjBL on the learning outcomes of students enrolled in the English Education Study Program at the Faculty of Cultural Sciences at Brawijaya University.

\section{Research Methods}

The current research is a quasi-experimental design with a pretest and posttest. The participants in this research were 65 students enrolled in Brawijaya University Malang's English Language Study Program at the Faculty of Cultural Sciences during the 2019-2020 academic year.

\subsection{Data Collection Methods}

Collecting data was conducted with a score of pre-test and post-test in the implementation of the project-based learning model for students of the Department of English Language Education Universitas Brawijaya Malang in the seventh semester. TOEFL test scores were analyzed usingstatistical methods, namely the one-way ANOVA test.

The purpose of this study is to collect information on the relationship between projectbased learning and student learning outcomes. Statistical techniques, specifically structural equation modeling, are often used to assess the responses' scores.

\subsection{Test}

To gather data on learning outcomes, pretest and posttest using TOEFL test were conducted at the start and end of the learning process, respectively.

\section{a. Pre TOEFL-Test}

The TOEFL Pre Test was administered to both classes during the seventh semester of the 2019/2020 school year after it was determined that the two classes were statistically identical (Ho was accepted if $t$ arithmetic <t table)..

\section{b. PreTest Learning-Outcomes}

PreTest Results are distributed to students at Brawijaya University Department of EnglishEducation to ensure that each class's initial interest is the same.

\section{c. ResearchTreatment}

This study's treatment was repeated 14 times by researchers in the experimental and control groups. This research treatment makes use of the same materials, lecturers, class 
conditions, and time period as the previous one. How to instruct an experimental class through the use of Project-Based Learning (PjBL).

\section{d. Post TOEFL Test}

After 14 days of treatment, students in both classes are given a post-test using the eTOEFL Test as a good and valid instrument test (Valid, Reliable, andPractical). The items in the test instrument are identical to those in the Pre Test.

\subsection{Instrument}

a. Questionnaire

1) Results questionnaire (for all students)

2) Project-Based Learning Questionnaire $(\mathrm{PjBL})$ model questionnaire (for Experimental class students).

b. E-TOEFL Prior to learning, tests are used to determine student learning outcomes and following treatment. TOEFL (Test of English as a Foreign Language This test is legitimate (valid, reliable, and practical). As a result, there is no need to calculate the content validity (content validity) of the test $t$, andthe validity of theTOEFL items does not need to be questioned because this test has been used in all countries; additionally, the instrument's practicality is very practical, as it is easy to read, understand, and includes an answer, allowing all assessors in a group to assess the same test. When the Project-Based Learning Model is used, video is used to capture material and images, especially during treatment time PjBL (Rizky, Asri, \& Purwoko Aji, 2017).

\subsection{Data Analysis}

To identify the formulation of the problem concerning the TOEFL test score, a one-way ANOVA test was used to determine the effect of treatment when more than two treatments were used (Montgomery, 2013). Determine the relationship between the method of achieving Project-Based Learning (PjBL)-based learning outcomes for students at Universitas Brawijaya Malang's Department of English Education using PLS study. PLS is a multivariate statistical technique for comparing multiple dependent and independent variables, according to Abdillah \& Jogiyanto (2015). When certain conditions exist in the data, such as a limited sample size, missing values, or multicollinearity, PLS is a variant-based SEM method designed to solve multiple regressions.

\section{Discussion}

\subsection{Measurement of Student Learning Outcomes in English Subjects}

The importance of TOEFL scores in the form of PjBL in the English language education program at Brawijaya University Malang is summarized in the Table 1 below.

It is known that the experimental class's pre-test score ranges from 367 to 483 with an average of 417.03, whereas the control class's ranges from 450 to 510 with an average of 470.53. Post-test scores in the experimental class range from 380 to 490 with an average of 450.06, while in the control class they range from 450 to 510 with an average of 476.67 .

According to a survey of English learning, up to60\% of English instructors thought the student learning outcomes in the classes they taught were satisfactory (had met the competency standards and learning outcomes planned in the RPS and RPP). However, in order to expand and change, improvements must be made. 
Table 1. Comparative Analysis Table of English Language Skills with Long-Distance Learning

\begin{tabular}{|c|c|c|c|}
\hline \multicolumn{2}{|c|}{} & Experiment & Control \\
\hline \multicolumn{2}{|c|}{ Respondent } & $\mathbf{3 5}$ & $\mathbf{3 0}$ \\
\hline \multirow{4}{*}{$\begin{array}{c}\text { Pre } \\
\text { Test }\end{array}$} & Min & 367 & 450 \\
\cline { 2 - 4 } & Max & 483 & 510 \\
\cline { 2 - 4 } & Mean & 417.03 & 470.53 \\
\cline { 2 - 4 } & DeltaMean & & 53.5 \\
\cline { 2 - 4 } & Stdv & 27.690 & 21.218 \\
\hline \multirow{4}{*}{$\begin{array}{c}\text { Post } \\
\text { Test }\end{array}$} & Min & 380 & 450 \\
\cline { 2 - 4 } & Max & 490 & 510 \\
\cline { 2 - 4 } & Mean & 450.06 & 476.67 \\
\cline { 2 - 4 } & DeltaMean & & 26.61 \\
\cline { 2 - 4 } & Stdv & 27.566 & 17.486 \\
\hline
\end{tabular}

According to the study, $15.4 \%$ of respondents said the student achievement in the courses they took was satisfactory. Students accept that they are supervised or monitored for orde and discipline both within and outside the classroom as a result of tertiary institutions implementing character education. 30.8 percent of student respondents reported they felt monitored or monitored in terms of order and discipline both within and outside the classroom as a result of character education implementation in tertiary institutions. 30.8 percent of student respondents said they felt monitored or monitored in terms of order and discipline both within and outside the classroom as a result of character education implementation in tertiary institutions.

According to check the data, $72.3 \%$ of students strongly agree that successful learning processes and processes influence student learning outcomes, while the remaining $27.7 \%$ agree. According to check the data, up to $78.5 \%$ of students strongly agree, while the remaining $21.5 \%$ agree, that prominent lecturers use exemplary habituation to reinforce students' positive behavior. $87.7 \%$ of students agree that the main curriculum, which is based on the project and learners used by the majority of lecturers in higher education today, should indeed be implemented. In view of the current project-based curriculum and the learning approaches used by the majority of lecturers in tertiary institutions at the time, $9.2 \%$ of student respondents said they were neutral.

According to check the data, up to $56.9 \%$ of students strongly agree and the remaining $43.1 \%$ agree that using new learning methods has raised student interest and helped them achieve improved learning outcomes. $83.1 \%$ of students believe their ability to communicate, think objectively, take responsibility, and have a social spirit is current and necessary. As many as $10.8 \%$ of student respondents said they believe collaboration, critical thinking, taking responsibility, and having a social spirit are important and acceptable now. In terms of cooperative processes, $66.2 \%$ of students believe that integrating Project-Based Learning $(\mathrm{PjBL})$ into the TOEFL learning process through E-Learning improves student learning outcomes. $73.8 \%$ of students believe that project-based learning increases learning outcomes, demonstrating the significance of this study.

\subsection{Effect of Project-Based Learning (PjBL) on Learning Outcomes Students in English courses}

In the experimental class, the one-way ANOVA test yields a value of sig equal to 0000 . $\mathrm{H} 2$ is agreed whereas sig $0.05(0.0000 .05)$, meaning that the treatment results of the three TOEFL tests in the experimental class, namely pre-and post-test, are distinct or important. The sig value for the control class $\mathrm{PjBL}$ is 0.031 , according to the test results. $\mathrm{H} 2$ is agreed 
since sig $0.05(0.0310 .05)$, meaning that the treatment results of the three TOEFL measures, including pre-and post-test, are distinct or important in the control class.

Table 2. PjBL Learning Hypothesis Test Results Against Student Learning Outcomes

\begin{tabular}{|c|c|c|c|}
\hline Hypothesis & Coefficient & T count & P-Values \\
\hline $\begin{array}{c}\text { PjBL E- } \\
\text { Learning-Based } \\
\text { Toefl Learning } \\
\text { Outcomes }\end{array}$ & 0,433 & 2,244 & 0,026 \\
\hline
\end{tabular}

It is understood that implementing Project Oriented Learning-Based Learning (PjBL) on TOEFL learning outcomes based on e-learning has a major impact on learning outcomes in VII semester students at Brawijaya University's science faculty culture of English Education research programs, with a p-value of 0.026 on learning outcomes. On TOEFL elearning-based learning outcomes, Project-Based Learning-Based Learning (PjBL) has a 0.433 impact.

\section{Conclusion}

Studying in higher education, especially in the field of education, in addition to providing sufficient theories, related to technical skills, is also required to have good personal abilities. Personal abilities such as soft skills are abilities that are absolutely fulfilled by individual students before and when they enter the workforce. As a solution to the above mentioned, continuous learning based on Project Based Learning (PjBL) can be concluded to have a significant effect on learning outcomes of e-learning based TOEFL and its influence is 0.433 . 


\section{References}

Mahanal, S., Darmawan, E., Corebima, a. D., \& Zubaidah, S. (2010). Pengaruh Pembelajaran Project Based Learning (PjBL) pada Materi Ekosistem terhadap Sikap dan Hasil Belajar Siswa SMAN 2 Malang. Bioedukasi (Jurnal Pendidikan Biologi), 1(1). https://doi.org/10.24127/bioedukasi.v1i1.179

Mansur, N. (2015). Pencapaian Hasil Belajar Ditinjau Dari Sikap Belajar Mahasiswa Nurdin Mansur Fakultas Tarbiyah dan keguruan UIN Ar-Raniry Banda Aceh. 3(2).

Montgomery, D., C. (2013). Statistical Quality Control: A Modern Introduction 7 th Edition.

United States: Jhon Wiley and Sons, Inc.

Rangkuti, A. N., and Hasibuan, W. S. (2019). Learning of Spatial Operations in 1st Grade of Junior High School (MTs.S NU Paringgonan) Ulu Barumun Sub-district Padang Lawas Regency. Budapest International Research in Linguistics and Education Sciences (BirLE) Journal. 2(1): 181-193.

Rizky, B. P., Asri, A. N., \& Purwoko Aji, D. K. (2017). Aplikasi Toefl Preparation Berbasis Ibt (Internet Based Test). Jurnal Informatika Polinema, 1(3), 13. https://doi.org/10.33795/jip.v1i3.107 